\title{
Spatial and temporal patterns of the zooplankton in the Westerschelde estuary
}

\author{
Karline Soetaert ${ }^{1, *}$, Pieter Van Rijswijk ${ }^{2}$ \\ ${ }^{1}$ Free University of Brussels, Pleinlaan 2, B-1050 Brussels, Belgium \\ ${ }^{2}$ Netherlands Institute of Ecology, Centre for Estuarine and Coastal Ecology, Vierstraat 28, 4401 EA Yerseke, \\ The Netherlands
}

\begin{abstract}
The invertebrate zooplankton fauna of the Westerschelde (Belgium and The Netherlands) was investigated during 2 yr by means of monthly samples along a salinity gradient. Copepods were usually the most abundant holoplanktonic metazoans except in the freshwater zone where Rotifera were most numerous. The combination of a classification technique and an ordination-regression technique proved to be a valuable tool for the analysis of such an extensive data set. The presence of 4 groups was established, representing spatially distinct populations but with temporally shifting boundaries. Few zooplankton species were truly estuarine in their distribution, but many were derived from nearby coastal waters. This intrusion of marine species started in spring, reaching their most upstream distribution and highest densities in summer-early fall, then declining and retreating from the estuary, disappearing in winter. Fringing this community was a transition group with low densities, but many species. This brackish-water community consisted predominantly of the calanoid copepod Eurytemora affinis. It appeared in late fall, spread out seaward to obtain its maximum density and distribution in winter-early spring. Densities then declined and the community was absent by late summer-early fall. The freshwater zone near the port of Antwerp, Belgium, was characterized by a paucity of large zooplankters, despite the high primary production in this zone. This is probably due to the low oxygen availability in this area. A canonical correspondence analysis revealed 2 major environmental axes. The salinity gradient (mainly spatial) explained most of the variance. Strongly correlated with this factor were dissolved oxygen content and secchi disc visibility. The temperature gradient (mainly temporal) was almost perpendicular to the salinity axis, indicating little or no correlation. Of lesser importance was the load of suspended matter, which was highest in the brackish area in autumn-winter. Chlorophyll content of the water was unimportant in explaining community structure. Copepod dry weight was maximal in spring in the brackish part $\left(500 \mathrm{mg} \mathrm{m}^{-3}\right)$; a lower maximum $\left(260 \mathrm{mg} \mathrm{m}^{-3}\right)$ was observed in summer in the marine part of the estuary.
\end{abstract}

\section{INTRODUCTION}

The Schelde is a medium-sized river in Europe, connecting 3 countries (France, Belgium, The Netherlands). It is characterized by a high degree of industrialisation (port of Antwerp, Belgium) and urbanisation. This makes the Schelde one of the most polluted rivers in Europe. The lower part of the Schelde, the Westerschelde, is the only remaining estuary in the delta area of the SW Netherlands, as coastal engineer-

\footnotetext{
- Present address: Netherlands Institute of Ecology, Centre for Estuarine and Coastal Ecology, Vierstraat 28, 4401 EA Yerseke. The Netherlands
}

ing works have changed the character of the other deltas in the region (Heip 1989).

Until now, few studies have been conducted on the aquatic ecology of the Westerschelde estuary. The last investigations of zooplankton date back to samples collected in 1968 (De Pauw 1973, 1975) and 1974 (Bakker \& De Pauw 1975, Bakker et al. 1977). In these studies, emphasis was on the brackish part of the estuary, and more specifically on the population of the calanoid copepod Eurytemora affinis. Based on these studies, the existence of a marine, phytoplankton-consuming community and a brackish, detritivorous community was postulated by Hummel et al. (1988). However, no detailed information on the spatial and temporal char- 
acteristics of these hypothetical communities was available.

Conditions in estuaries are very variable in both time and space, and this likely will be reflected in changes in communities. Moreover, changes in climate (Hansen et al. 1988) could alter compositions and abundances of zooplankton and as much can be said about increasing human pressure on the ecosystem. Knowledge of the variability of the zooplankton communities and of the ecological preferences of its constituents can help us to predict effects of changes, whether induced by man or not.

Besicles the fact that descriptive studies are useful inasmuch as they provide lite history information of species, any attempt to measure community fluxes should be put into perspective. As rates in zooplankton populations are usually (and necessarily) performed at the species level, detailed information on the spatio-temporal importance of species is mecessary before attempting to quantify specific processes. Moreover, as an increasingly large effort is devoted towards modelling of the aquatic environment, monitoring becomes more and more important. A good monitoring strategy (maximum of results with a minimum of effort) requires a thorough baseline study of the ecosystem.

This study presents analyses of the temporal and spatial patterns of abundance of zooplankton populations over a 2 yr period in the Westerschelde. Spatial scales are in the order of kilometres and greater, and sampling was done monthly. This study is part of multidisciplinary research of the Westerschelde, aiming at an ecosystem model of the entire estuary.

\section{MATERIAL AND METHODS}

Site description. The study area was in the lower estuarine part of the Schelde, called the Westerschelde (Fig. 1). Based on hydrological and morphological data, the estuary can be divided in 2 major regions (Peters \& Sterling 1976). Seaward is a well-mixed region characterized by a complex system of channels. Upstream, there is only 1 main channel.; this is the weakly stratified part of the estuary. The Westerschelde is subject to a large anthropogenic stress, due both to the discharge of industrial and urban effluents (Duursma et al. 1988) and to dredging activities (Belmans 1988). The estuary has a relatively high residence time of about $75 \mathrm{~d}$ or 150 tides (Heip 1988).
Sampling and sample processing. Zooplankton and auxiliary environmental data were collected on 24 monthly cruises from April 1989 to March 1991. During each survey, 12 stations were sampled along a transect (Fig. 1), ranging from Vlissingen (1, the most seaward station) to Antwerp (12). At the time of sampling, no correction for the phase of the tide was made. The tidal excursion in the Westerschelde typically is close to the distance between 2 stations.

Zooplankton was sampled by means of a pump (Pleuger type no. 64 with a capacity of $2001 \mathrm{~min}^{-1}$ ). Water was pumped from $2.5 \mathrm{~m}$ below the surface, 2.5 $m$ above the bottom and mid-depth. From each depth, $100 \mathrm{l}$ of water was poured over a $55 \mu \mathrm{m}$ mesh. These 3 samples were then combined and fixed in buffered $4 \%$ formaldehyde. Due to the high load of suspended matter, further processing of the samples was required. Lighter organisms were separated from heavier material by means of density gradient separation, using Ludox. This technique, often used in meiobenthic studies, proved to be useful in zooplankton research as well (Baretta 1980).

For various reasons, 8 samples could not be processed (October 1989, Stns 1, 2, 11 \& 12; April 1990, Strs 2, 3 \& 4; May 1989, Stn 7). The remaining 280 samples were analyzed for total zooplankton density and taxonomic composition up to the highest practicable level. Subsamples for counts of large zooplankton were taken by pipette $(5 \mathrm{ml})$ after the contents of a sample had been randomly distributed by a series of stirrings and backstirrings. At least $10 \%$ of the total sample was analyzed. For small zooplankton (e.g. copepod nauplii, rotatoria), a smaller subsampling volume was obtained (1 to $2 \%$ of total sample). Copepod biomass was calculated by length-weight regressions: cephalothorax lengths of copepods were measured using a digitizing tablet, length-weight 
regressions were either drawn from the literature or determined in the lab. Copepod biomass was estimated for the first year only.

Measurements of temperature, salinity, dissolved oxygen concentration, chlorophyll content, secchi visibility, suspended matter content, concentration of particulate and dissolved organic carbon were made at each sampling station.

Data analysis. Analysis of survey data proceeded as follows: species communities were delineated by means of the classification technique TWINSPAN (Hill 1979). Although TWINSPAN works on presences and absences, it can be used quantitatively by defining pseudospecies, which takes into account the species abundances. For this analysis, pseudospecies cut levels were positioned logarithmically; more weight was given to more numerous pseudospecies.

The relationship between species, stations and environmental data was investigated by means of a Canonical Correspondence Analysis (CANOCO) (Jongman et al. 1987, Ter Braak 1988, 1989). This is a technique performing both regression and ordination of the data concurrently. By means of CANOCO, species, samples and environmental variables can be arranged in a 2-dimensional space such that similar entities are close to one another and dissimilar entities are far apart. The arrows in a CANOCO plot represent environmental variables such that their size indicates their explanatory power. The angle between environmental arrows indicates correlation between factors: $0^{\circ}$ indicates strong positive, $180^{\circ}$ strong negative, $90^{\circ}$ indicates no correlation. The occurrence of a species can be related to the environmental variables by perpendicularly projecting their position on the environmental axes in the same plot. Sample scores are weighted averages of species scores and the combination of the sample and species positions in the plot yields an insight into what species are responsible for a certain position of the sample. For more information we refer to Jongman et al. (1987) and Ter Braak (1988).

Diversity was calculated as Hill's diversity numbers of order 0 and 1 (Hill 1973), with $\mathrm{N} 0=$ number of species, $N 1=\exp \left(H^{\prime}\right)$ with $H^{\prime}=-\sum_{p_{l}} \ln _{p_{1}}$, the ShannonWiener diversity index. Both are expressed in equivalent number of species.

\section{RESULTS}

\section{Abiotic environment}

Estuaries are characterized by their environmental gradients, both temporally and spatially (Fig. 2). The most pronounced spatial gradient in the Westerschelde was salinity. It decreased from more than $30 \%$ at the mouth to about freshwater near Antwerp. Saline waters protruded deeper into the estuary in summer and fall, when the river discharge was lower. Salinity did not surpass $30 \%$ in winter. The oxygen content of the water ranged from oversaturation in spring-summer in the marine part to very low levels near Antwerp on most occasions. Temperature increased a few degrees from the mouth to Antwerp, but its main gradient was from winter (minima of $4{ }^{\circ} \mathrm{C}$ and lower) to summer (maxima above $20^{\circ} \mathrm{C}$ ). Secchi disc visibility (not figured) decreased, while the load of suspended matter generally increased with increasing distance from the mouth. A turbidity maximum was usually observed near the brackish part of the estuary. Here the secchi disc visibility was lowest, while particulate organic carbon content (not shown) and the load of suspended material was maximal. Dissolved organic carbon (DOC) generally increased from the mouth to Antwerp. In March 1990 an exceptionally high value was measured about $30 \mathrm{~km}$ upstream. Chlorophyll values usually were $<20 \mu \mathrm{g} \mathrm{l}^{-1}$, except near Antwerp. where extremes of $>200 \mu \mathrm{gl}^{-1}$ have been measured in late summer.

\section{Gross taxonomic composition}

Holoplanktonic taxa frequently observed included Rotifera, Cladocera, Copepoda and Appendicularia (Figs. 3 to 5). On most occasions, Copepoda (copepodids and nauplii) were the most abundant taxon, but Rotifera were nearly always most numerous around Antwerp, and sometimes in other stations (brackish zone) as well (Fig. 3). Chaetognata, Amphipoda, Isopoda and Cumacea (not shown) were observed occasionally; Mysidacea (not shown) were found more frequently, although the sampling method was not suited for the catching of these groups. Gelatinous zooplankton was sometimes present but inadequately sampled. At some occasions, the most abundant organism in the water column was Noctiluca miliaris, reaching densities of $>1000$ ind. $1^{-1}$ (Fig. 3).

Within the meroplankton (Fig. 3), larvae of Mollusca (Gastropoda and Bivalvia veligers), Polychaeta (Nectochaeta and Trochophora larvae), Cirripedia (cyprid and nauplii), Bryozoa (cyphonautes) and Echinodermata (pluteus) were observed frequently; the larvae of Decapoda (not shown) were observed occasionally in the marine zone. Truly benthic taxa were observed in high quantities in the water column mainly in the vicinity of Antwerp; they consisted predominantly of nematodes (Fig. 3, up to 25 ind. $\mathrm{l}^{-1}$ ) and oligochaetes (not shown, up to 1 ind. $\mathrm{I}^{-1}$ ). 

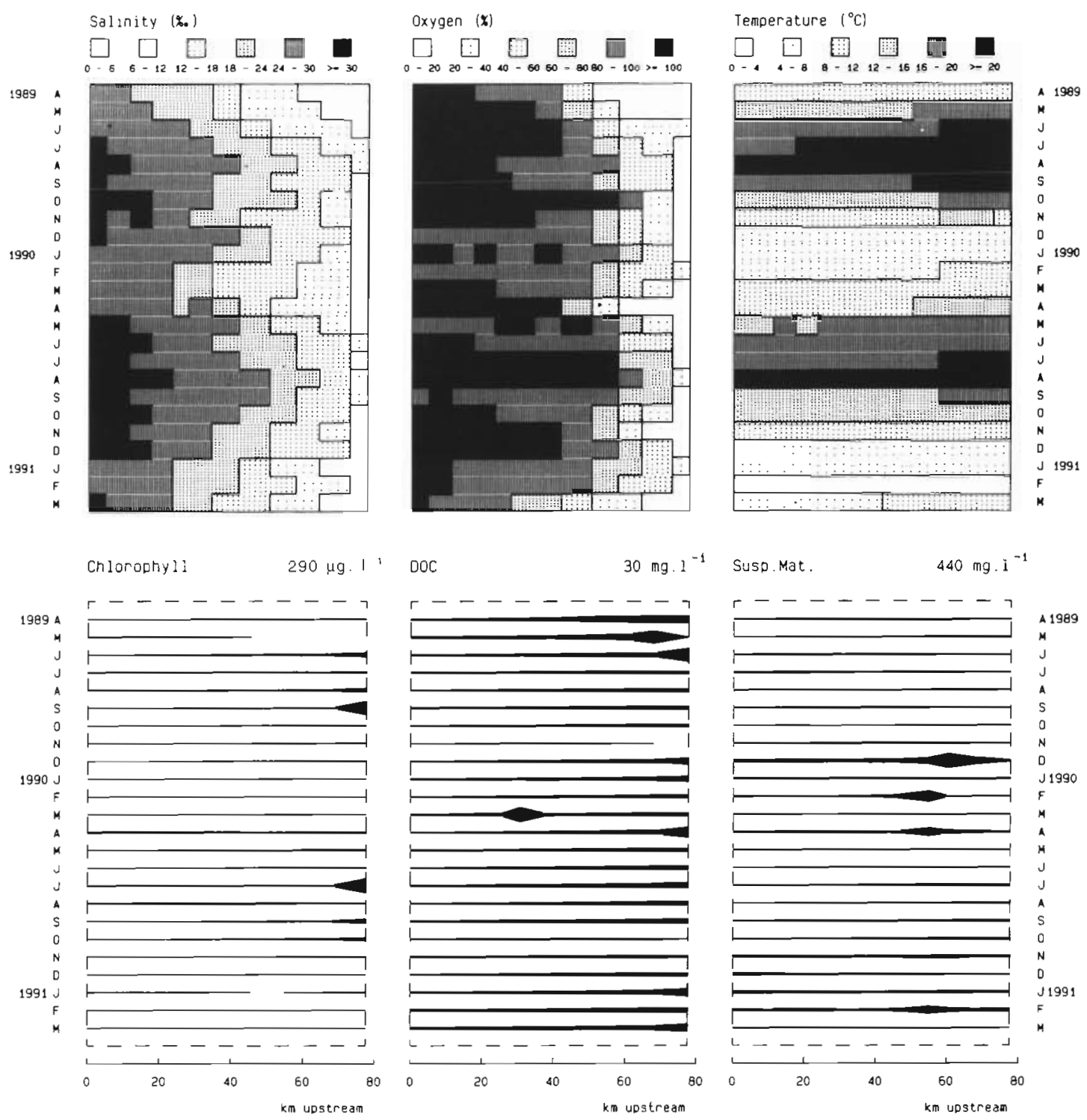

Fig. 2. Spatio-temporal plots of environmental factors in the Westerschelde estuary. The spatial axis (horizontal) represents the distance from the mouth $(\mathrm{km})$. The temporal axis (vertical) consists of monthly transects from April 1989 to March 1991

\section{Analysis of holoplankton distribution}

Multivariate analyses were performed on the larger holoplanktonic taxa only. Meroplankton and benthic taxa, as well as copepod nauplii and Rotifera were not considered. The latter 2 were left out because taxonomic determinations were only possible at the genus level and their high densities would blur the analysis Moreover, some of the rotifers were very small and might have been inadequately sampled with our $55 \mu \mathrm{m}$ mesh.

Using TWINSPAN, we delineated 4 communities (Fig. 6). A.t the first division, Communities $1 \& 2$ and $3 \& 4$ were separated. The next 2 divisions then yielded the following groups
Twin 4, the 'marine' community, was first observed in spring at the most seaward stations; towards summer and early fall this community was found almost over the entire estuarine range, after which its distribution diminished, disappearing in winter (Fig. 6). Twin 4 is characterized by its high density and diversity. The community is present in saline, well-aerated, relatively transparent and warm waters (Table 1). Its main constituents are the calanoid copepods Pseudocalanus elongatus (present in late spring-early summer), Temora longicornis (late spring-summer), Centropages hamatus (spring-early summer), Acartia clausi (summer) and Paracalanus parvus (late summer-early fall) (Fig. 4). The harpacticoid copepod Euterpina acutifrons and in 1990 the cyclopoid 

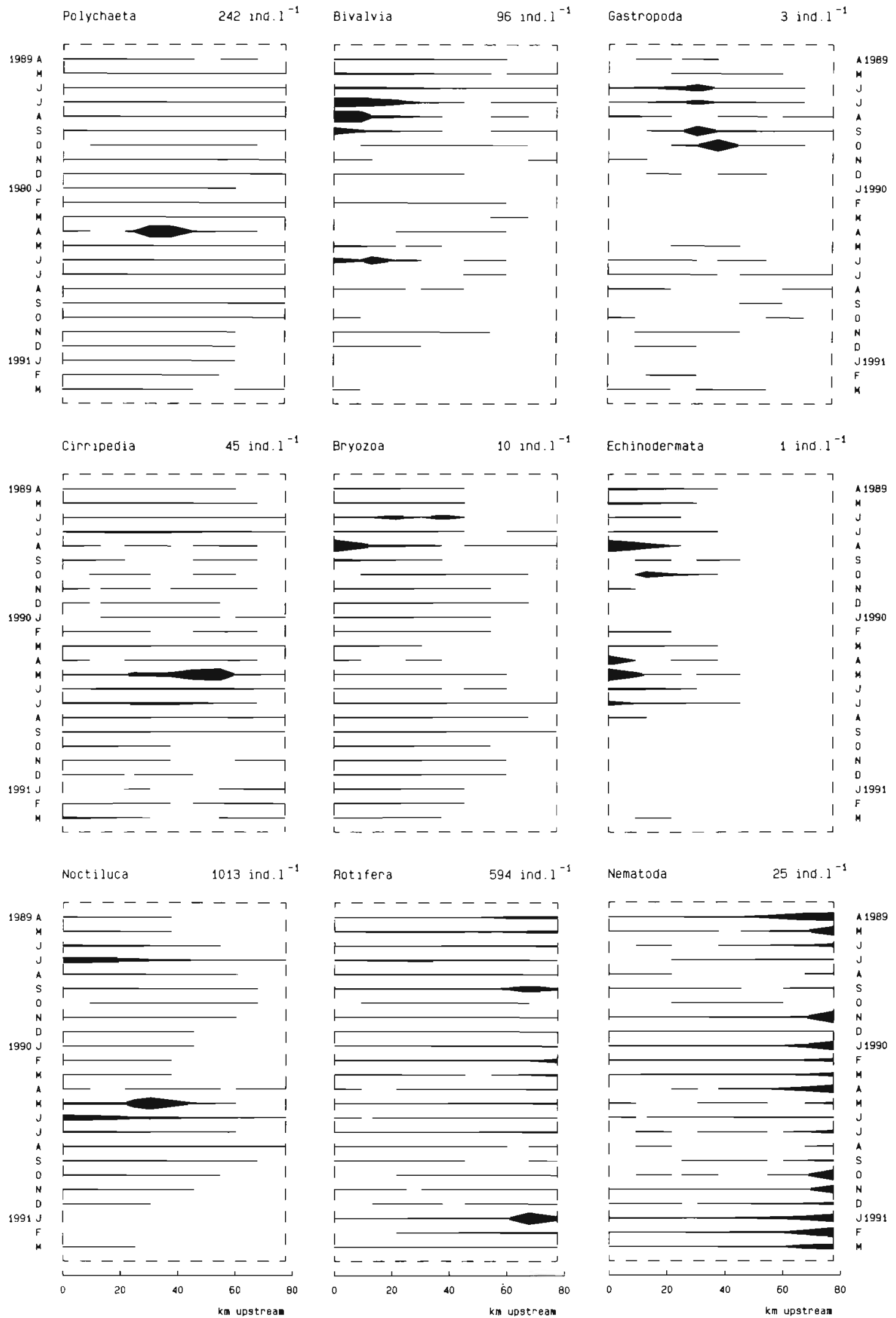

Fig. 3. Spatio-temporal plots and maximum densities of meroplankton (larvae of Polychaeta, Bivalvia, Gastropoda, Cirripedia, Bryozoa and Echinodermata), Noctiluca miliaris (Protozoa), Rotifera and Nematoda 

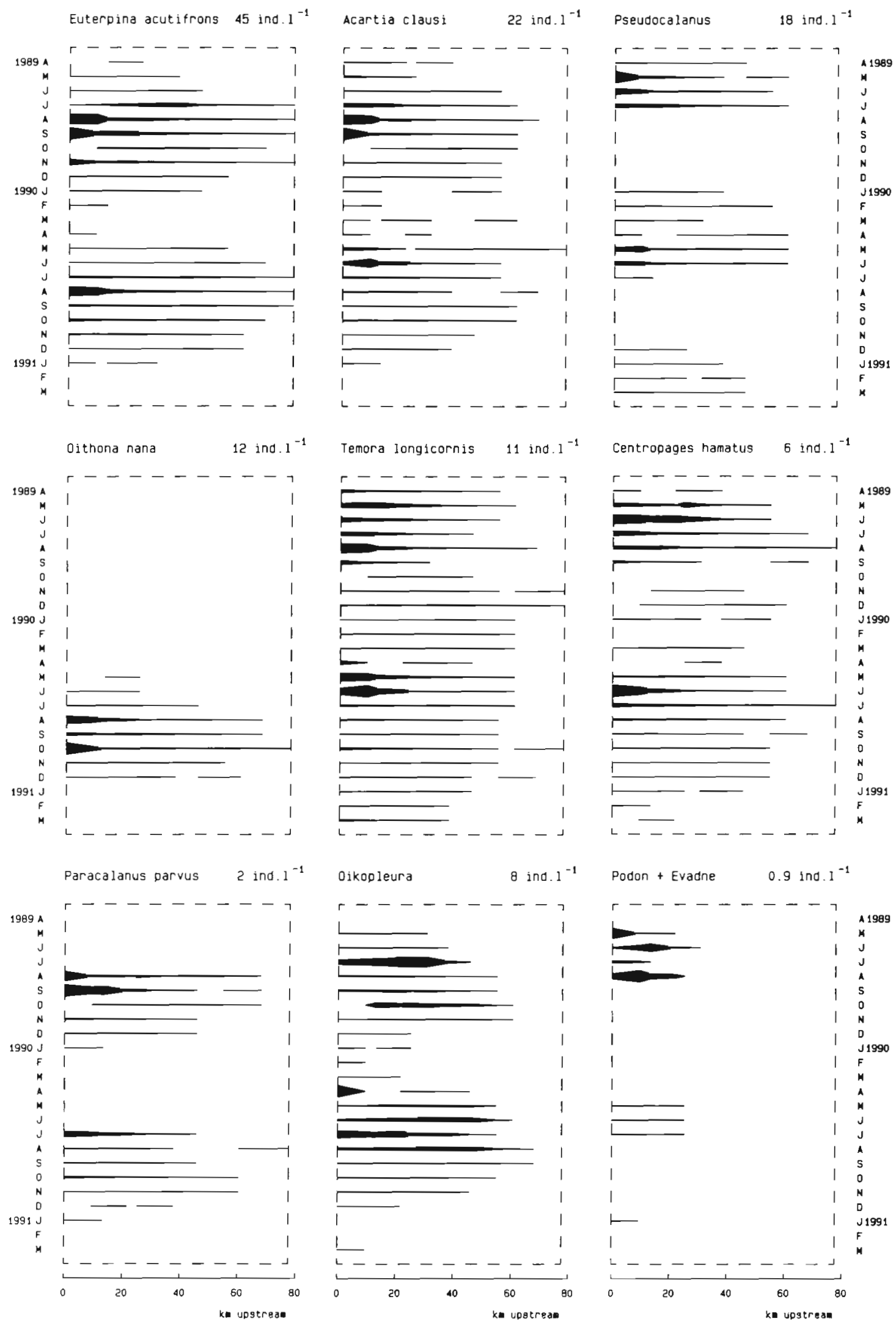

Fig. 4. Spatio-temporal plots of 'marine' species arranged according to decreasing density 

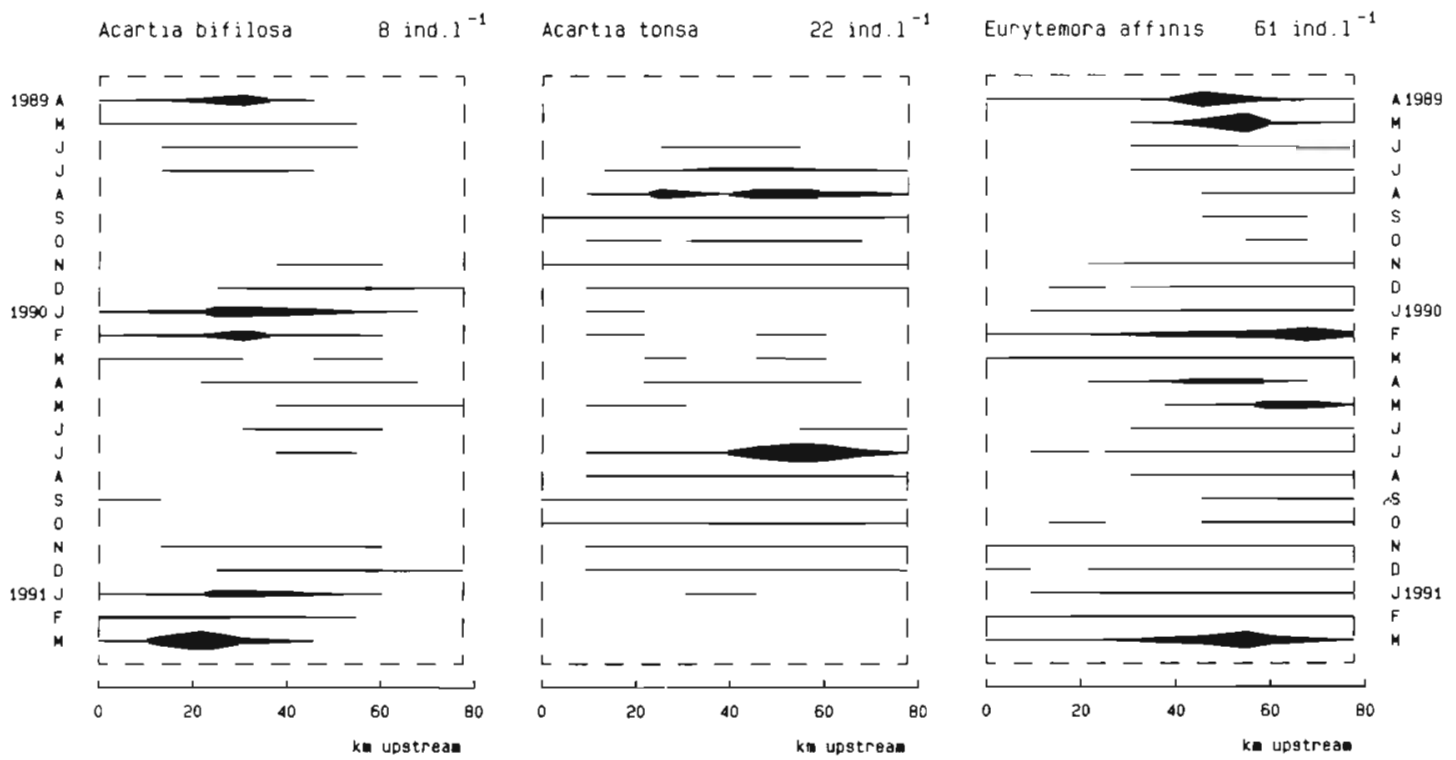

Fig. 5. Spatio-temporal plots of estuarine species

copepod Oithona nana were abundant in late summer to the fall. Non-copepod species belonging to this community were the appendicularian Oikopleura dioica and the cladocerans belonging to the genera Evadne and Podon. Densities of all species belonging to this Twin group were highest at the mouth of the estuary and declined more or less continuously upstream.

Twin 3 fringed the marine Twin 4 community in the spatio-temporal plot and was absent in summer (Fig. 6). Densities are low, but diversity is high. It was found at somewhat lower temperature, oxygen content and salinity than Twin 4. Transparency of the water was low (Table 1). The calanoid copepod Acartia bifilosa was a constituent of this group in winter-spring (Fig. 5). Other members are the species characterizing Twin 4 and Twin 2, though here they are present in considerably lower quantities. As such Twin 3 can be considered a 'transition' community from Twin 4 to Twin 2 .

Twin 2, the 'brackish' community, was present from late fall to summer in the brackish part of the estuary. In midwinter, this community was found upstream to about $20 \mathrm{~km}$ from the mouth, while in summer its area was restricted to the more upstream part of the estuary (Fig. 6). It is a very dense community but with. low diversity. It was found in water with relatively low salinity and temperature, not well aerated and with a high load of suspended matter (Table 1). It consists primarily of 1 species, namely Eurytemora affinis, which reaches maximum densities of 61 ind. $\mathrm{l}^{-1}$ (Fig. 5). Freshwater species were nearly absent.

Twin 1 was found in the area around Antwerp up to about $60 \mathrm{~km}$ upstream, in nearly fresh water with very low oxygen content. The amount of chlorophyll was very high. This Twin group was characterized by the very low densities of the zooplankton groups considered; low numbers of freshwater cyclopoids and some cladocerans may be present. Diversity was very low (Table 1). Benthic taxa and Rotifera have their maximum abundance in this Twin group (but these were not considered in the analysis). Stalked protozoans were always very abundant in this area, but these were not enumerated.

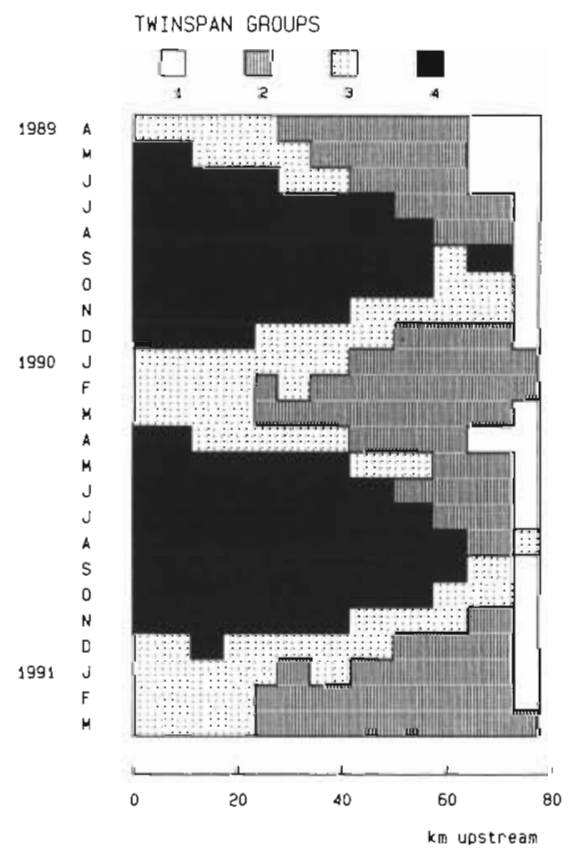

Fig. 6. Spatio-temporal plot of Twin groups 
The calanoid copepod Acartia tonsa, though abundant at times (Fig. 5), did not fit nicely in the separation imposed by TWINSPAN, and was present in Twin 4 as well as in Twins $2 \& 3$. It was a typical summer species, present in the middle and estuarine reaches of the Westerschelde. Some copepod species were never abundant in the estuary. Among them are members of the genera Corycella and Hemicyclops, usually observed at low temperatures in the marine to middle part of the estuary (Twins $3 \& 4$ ). The pelagic harpacticoid Microsetella norvegica and the juvenile stages of parasitic copepods belonging to the genus Lernaeocera were observed erratically. The calanoid $A$. discaudata and juveniles of the genus Calanus were observed on very few occasions.

A CANOCO analysis did not produce a clear-cut separation of the Twin groups, yet it is useful to visualize the environmental preferences of the main species in the estuary, as well as the major gradients (Fig. 7). The environmental factors and the species composition of the stations were analysed concurrently; spatial and temporal characteristics of the stations were correlated with the main axes after performing the CANOCO analysis. As such, the position of a station in the CANOCO biplot is not directly influenced by its spatial and temporal features. Yet, by adding these later on, the major environmental gradients can still be related to spatio-temporal effects.

Two important environmental gradients are obvious in the biplot. The largest axis (and thus explaining most of the variance) represents the salinity gradient, which is strongly and positively correlated with oxygen content and secchi visibility. Higher values of dissolved organic carbon are consistently found in the lower salinity regions. Almost perpendicular to the salinity gradient (and correlated factors) is the temperature gradient, indicating the lack of correlation between these 2 gradients. In fact, the salinity gradient reflects more the spatial, while the temperature gradient reflects more the temporal, variation. Less important in explaining community structure were particulate organic carbon and the amount of suspended matter. These are strongly interrelated and show a weak correlation with both the time and the space axes. Chlorophyll content is only weakly correlated with other variables and plays a minor role in explaining community structure.

The position of the species in the ordination diagram reveals 2 groups, separated by the salinity gradient (and the correlated factors). To the left of the temporal axis is a ribbon of species occurring at higher salinities: from Acartia bifilosa at low temperatures to Euterpina acutifrons at high temperatures. To the right of the time axis are few species which are common in the low-salinity region (from Bosmina sp. to $A$. tonsa).

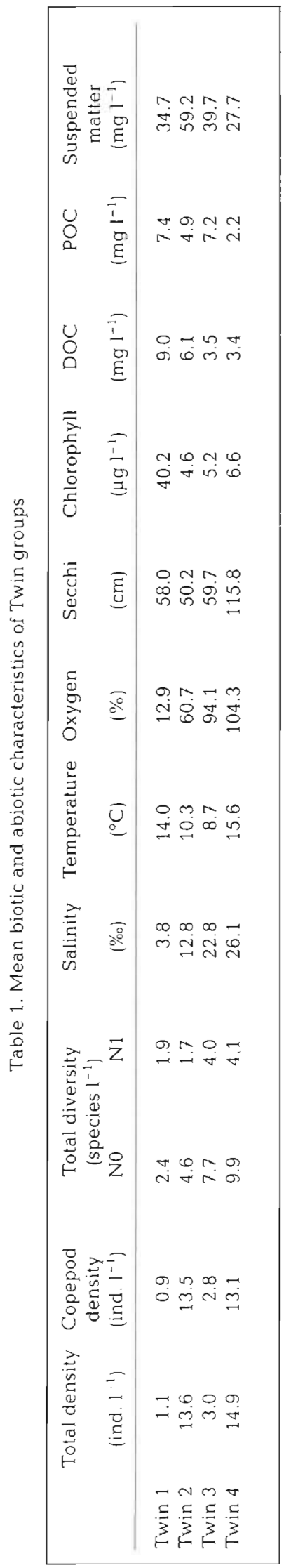


Fig. 7. Canonical correspondence analysis (CCA) of zooplankton in the Westerschelde: $X$ and $Y$ are the first 2 axes in CCA ordination. Represented in the main figure are species scores ( $)$ and environmental variables (arrows); time and space were correlated to the $X$ and $Y$ axes after performing the CANOCO analysis. Position of the Twin groups is shown in the inset

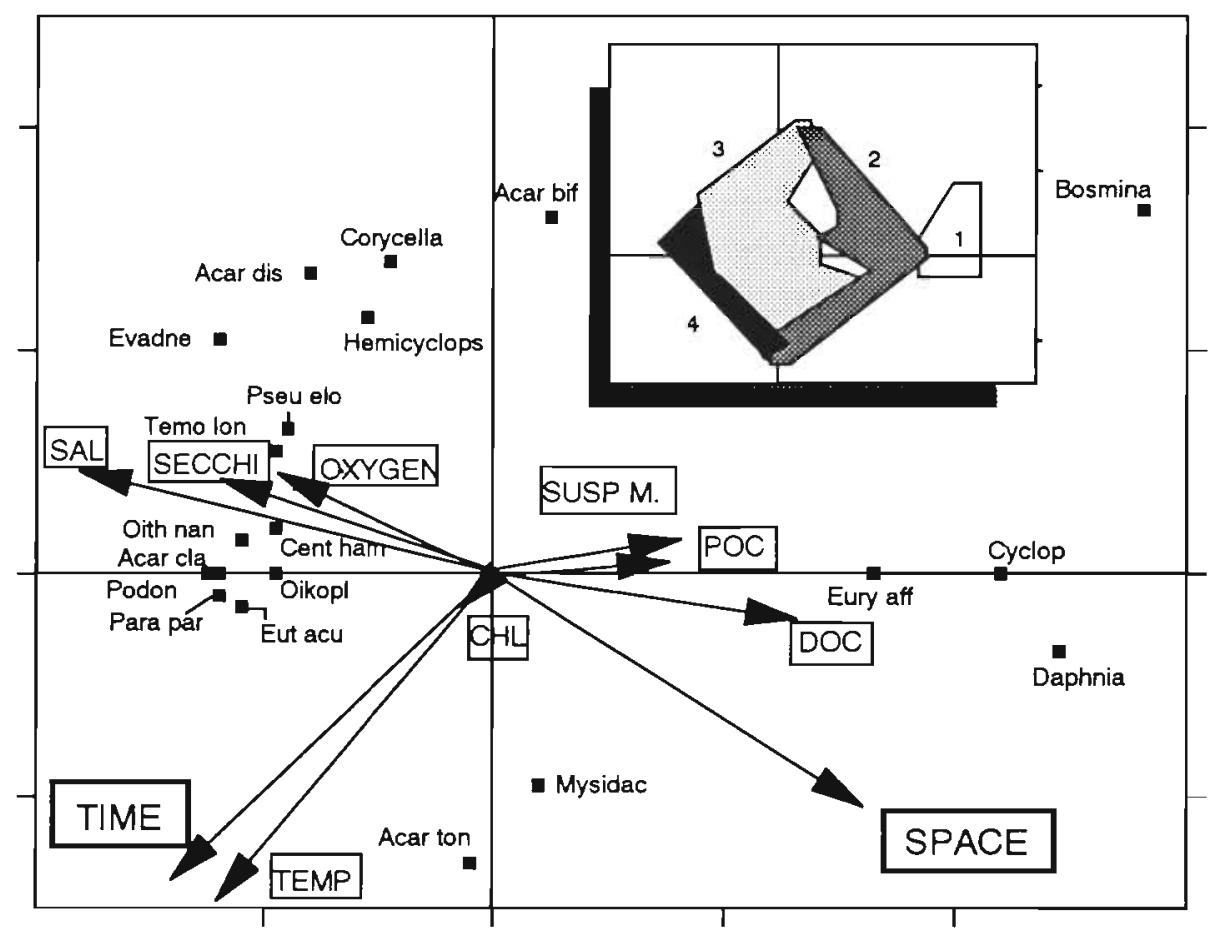

There are no species in the centre of the ordination diagram. This could indicate that generalists, i.e. species living under the entire range of environmental conditions, are absent in the estuary.

The sampling effort appears to be sufficiently close both in time and in space so as to form a dense cluster of stations in the CANOCO plot (inset). Only the stations belonging to Twin 1 (freshwater community) are visibly separated from the remainder. The other Twin groups together form a rectangular cluster, stretched along the temporal and spatial axis. They are not separated from one another by means of gaps, but nevertheless occupy distinct positions in this rectangle. The marine community (Twin 4) has a strong spatial component, while the brackish community (Twin 2) is centered around the species Eurytemora affinis and stretched along both the temporal and spatial axis. Twin 3 takes an intermediate position between Twins $2 \& 4$.

\section{Copepod density and biomass}

In summer highest copepod densities were observed in the marine part of the estuary (up to 78 copepodids and adults $l^{-1}, 508$ nauplii $l^{-1}$ ) (Fig. 8). This was mainly due to the presence of relatively small copepods (Euterpina acutifrons, Acartia clausi, Oithona nana). Thus, despite these high densities, total copepod dry weight reached at most $250 \mathrm{mg} \mathrm{m}^{-3}$. The brackish part in summer was characterized by $A$. tonsa, which was far less abundant (max. 22 copepodids and adults $1^{-1}$. 114 nauplii $\mathrm{l}^{-1}$, max. biomass $71 \mathrm{mg} \mathrm{m}^{-3}$ ). In winter high densities of Eurytemora affinis (max. 61 copepodids and adults $l^{-1}, 265$ nauplii $l^{-1}$ ), a relatively large copepod, were observed in the brackish part. The marine part was depauperated then. Copepod dry weights were about $500 \mathrm{mg} \mathrm{m}^{-3}$ in the brackish part in winter, and were negligible in the marine part.

\section{DISCUSSION}

Temporal and spatial patterns in community parameters may be influenced amongst others by environmental factors, by competition or predation, by chance events and in general by the complicated interaction of all these factors. In estuaries, the potential range of a zooplankter is determined by salinity, temperature, food availability and turbidity. Advective and dispersive processes control the influx of zooplankton from source areas and the continuous loss downstream. They tend to increase the potential range of species, while competition and predation effects tend to decrease its range. In highly polluted areas such as the Westerschelde, anthropogenic activities may be important too as eutrophication can on the one hand enhance biological productivity, while heavy pollution or microbially induced anaeroby may decrease an organism's wellbeing.

The zooplankton of the Westerschelde comprises a mixture of neritic and endemic estuarine species much 

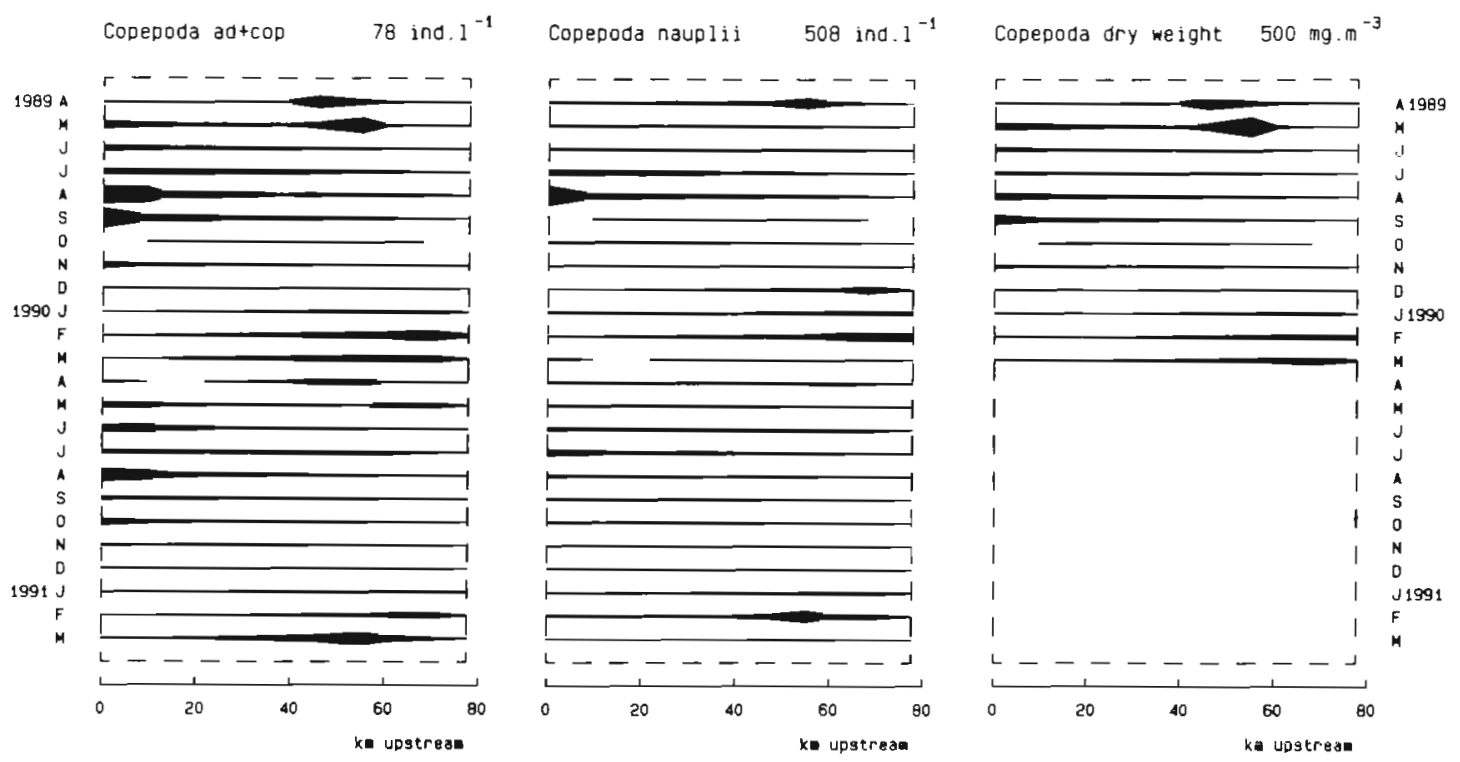

Fig. 8. Spatio-temporal plots of copepod density (adults + copepodids), naupliar density and copepod dry weight (first year only)

like what was described from other temperate estuaries (Collins \& Williams 1982, Miller 1983, Baretta \& Malschaert 1988, Day et al. 1989, Villate 1991b). The majority of species observed in the estuary were typical constituents of the North Sea zooplankton: Temora longicornis, Acartia clausi, Pseudocalanus elongatus, Centropages hamatus, Paracalanus parvus, Oithona nana, Podon spp., Evadne spp., Oikopleura dioica (Fransz et al. 1991). They were seen to enter the Westerschelde concurrently with the dispersive intrusion of marine waters in spring and subsequently had colonized the major part of the estuary in summer. In winter, when advective transport became more important and salinity decreased, they disappeared from the estuary. Nauplii of all marine copepod genera were observed in appreciable quantities, which suggests that populations did not solely persist due to replenishment from neritic influx but also by reproduction in the estuary itself.

Other Westerschelde species can be classified as purely estuarine and they have other life-strategies. Among them were 2 Acartia species which had their main distributional area at distance from the sea. $A$. bifilosa in the central part and $A$. tonsa in the upstream part. Their occurrence in the estuary seemed to be limited in time as well, suggesting that repopulation occurs through the hatching of dormant eggs from the sediment, a phenomenon frequently observed in species of the genus (Grice \& Marcus 1981, Viitasalo 1992). The most important species in the Westerschelde in terms of biomass was the truly estuarine calanoid copepod Eurytemora affinis. This is a typical brackish water constituent which is numerous in many
European estuaries (Hirche 1974, Collins \& Williams 1981, Roddie et al. 1984, Soltanpour-Gargari \& Wellershaus 1984, Castel \& Veiga 1990) as well as in North American estuaries (Allan et al. 1976. Stepien et al. 1981, Miller 1983). In the Westerschelde the species never completely disappeared from the plankton but was most prominent in winter-early spring, whereas in summer it seemed to be outcompeted by $A$. tonsa. This phenomenon is typical for many temperate estuaries and has been attributed to selective predation, seasonal changes in food quality or reproductive strategy (Hirche 1992). The optimal development of $E$. affinis appears to be in the range of salinity from 0.5 to $5 \%$ (Soltanpour-Gargari \& Wellershaus 1984, Castel \& Veiga 1990) and breeding populations were even found in freshwater areas of the Elbe (Heckman 1986). In the Westerschelde salinities of 0 to $5 \%$ are in the vicinity of Antwerp but remarkably enough $E$. affinis was never abundant there. Instead it was most prominent in the zone more downstream, at higher salinities. Even more so, almost no large zooplankters were ever observed in appreciable quantities near Antwerp. Yet highest chlorophyll values were measured here and primary production amounted to about $900 \mathrm{~g} \mathrm{C} \mathrm{m}^{-2}$ yr ${ }^{1}$ (A. Van Spaendonk, J. Kromkamp \& P. de Visscher in press). However, due to sewage effluents, the organic load is also high here and respiration of this detritus by heterotrophic bacteria leads to severe anoxia in the water (Billen et al. 1988, Goosen et al. 1992). It is very likely that these bad conditions prevent the brackish-water species from thriving on the abundant algal food source there. Rotifera seemed to be the only metazoan holoplankters able to withstand the anaero- 
bic conditions of these waters, and even so we observed many empty loricas (dead individuals) on several occasions. Among the protozoans, stalked ciliates were present in very large quantities in this area, but these were not considered in this study (too small). Also peaking in the low-salinity range were typical benthic taxa: nematodes (max. 25 ind. $\mathrm{l}^{-1}$ ) and oligochaetes (max. 1 ind. $\mathrm{l}^{-1}$ ). These animals probably enter the plankton due to dredging activities (Belmans 1988) and resuspension caused by tidal currents or wind-induced waves. Being light and unable to swim they are then subjected to the same transport processes which affect the lighter sediment particles and are hence amassed in the vicinity of the turbidity maximum.

Three Acartia species were common in the Westerschelde and their distribution patterns indicate both a temporal and spatial separation. $A$. clausi and $A$. tonsa both peaked in summer, but the former species resided in the marine part, the latter mainly in the brackish area. A. bifilosa, a winter species, was present in the central estuarine part. Although the sequential and spatial separation could as well be due to each species reacting differently to the physical environment, these distinct species distributions are at least consistent with a competition hypothesis. Indicative in this respect is the fact that in some studies these species seemed to have other environmental preferences. A. clausi, a summer species in this study, has been found at much lower temperatures (Bay of Biscay: Villate 1991a; Arcachon Bay, France: Castel \& Courties 1982; U.S. and Canadian estuaries: Day et al. 1989). A. tonsa, truly estuarine in this study, is a very tolerant species, being found in coastal zones as well as in estuaries (Paffenhöfer \& Stearns 1988, Tackx et al. 1990, Fransz et al. 1991, Bakker \& Van Rijswijk unpubl.). In the Bristol Channel and Severn Estuary (England), $A$. clausi is a summer species (as in the Westerschelde) and its distributional area shows no overlap with the winter-spring dominant $A$. bifilosa (Collins \& Williams 1981). In the Severn Estuary, A. bifilosa does not disappear from the estuary and it is found more upstream in summer. In the Westerschelde on the other hand, A. bifilosa could not retreat more upstream in summer as here $A$. tonsa occupied this area, a species which was not mentioned by Collins \& Williams (1981).

In the marine zone of the estuary, a succession of large species in spring-early summer (Pseudocalanus elongatus, Temora longicornis, Centropages hamatus) and smaller species (Acartia clausi, Paracalanus parvus, Euterpina acutifrons, Oithona nana) in late summer-fall was apparent. A similar trend was reported from the coast off Galicia (Valdes et al. 1990) and from the Bay of Biscay (Villate 1991a). According to these authors, small copepods, with their higher rates of development, have competitive advantage in high phyto- plankton concentration and should thus be indicative of blooms. In the Bay of Biscay, predatory control was important too with medusae and chaetognaths preying on smaller fish preying on larger zooplankton (Villate 1991a). In the marine zone of the Westerschelde, chlorophyll content and phytoplankton productivity peak both in spring and in summer (samples from 1990; A. Van Spaendonk, J. Kromkamp \& P. de Visscher in press), and as such one could wonder why small copepods - if they are more competitive - are present only in summer. The size of algal cells is also known to have an important influence on the growth rate and fecundity of copepods (Bakker \& Van Rijswijk 1987, Van Rijswijk et al. 1989). It could be that a different size distribution of the main phytoplankton species in spring and summer is causing the shift in copepod size. Indicative are differences in the chlorophyll/primary production ratio of the 2 peaks, being high in spring, while in summer the mass-specific primary production is higher, suggesting smaller algal cells. In the Oosterschelde, a nearby estuarine system, Tackx et al. (1988) found that $T$. longicornis and C. hamatus fed on large (>20 $\mu \mathrm{m}$ SED) particles, while the smaller Acartia species fed more on smaller particles. Nothing is known of the distribution of other possible food sources nor of copepod predators in the Westerschelde.

In this study, 2 different techniques have been used to summarize the large amount of data. The classification technique TWINSPAN (Hill 1973) was used to group stations that are sufficiently similar and thus to separate distinct assemblages. CANOCO (Jongman et al. 1987. Ter Braak 1988) was used to clarify patterns of relationship between the biotic and environmental data simultaneously. As classification and ordination emphasize different aspects of the community data (i.e. discontinuity versus continuity), the combination of both techniques is useful to reveal the basic structure of the data (Gauch 1982). The groups distinguished by TWINSPAN can be represented in the CANOCO graph which aids in understanding the divisions imposed. Moreover, the notion of distinctiveness of assemblages as put forward by TWINSPAN is put in its proper perspective by the continuous representation of the data in ordination techniques. Indeed in this study only Twin 1 (the freshwater community) seemed to be clearly separated from the other groups, whereas Twins 2 to 4 only occupied different ranges in an otherwise rather dense area (Fig. 7). So one could even wonder about the validity of these Twin groups. We believe that they are true entities, as (1) although TWINSPAN has no knowledge on the spatial and temporal characteristics of each sample, stations belonging to a Twin group are spatially and temporally related to one another and differentiated from the other Twin groups (Fig. 6). Different Twin groups were found when dif- 
ferent environmental conditions prevailed (Table 1) (2) The biotic characteristics (density and diversity; Table 1) of the Twin groups were also distinctly different, with Twins $2 \& 4$ having highest density, Twins 3 \& 4 having highest diversity. Even Twin 3, although composed of species also belonging to Twins $2 \& 4$ deserves its own status, being distinct from Twins $2 \& 4$ by its low densities. One way of circumventing transitions between groups and thus producing more distinct assemblages is by taking fewer samples and as such eliminating amphibious conditions. However, the strength of an elaborate survey such as this one, with a sufficiently narrow spatio-temporal grid, is that one can observe gradual changes in communities, which moreover occupy different ranges at different times of the year. If samplings were limited to a few sites on few occasions, what would appear as a temporal succession of species at 1 site, could really represent a movement of different populations in the estuary as a response to changing environmental conditions

Acknowledgements. This article is dedicated to C. Bakker, on the occasion of his retirement from the N.I.O.O. We thank Drs C. Bakker, P. Nienhuis, V. Escaravage and P. Herman for reading the manuscript and providing helpful comments. The crew of the 'Luctor' is thanked for help in sampling. A. A. Bolsius is thanked for his finishing touch on the graphics. K. S. acknowledges a grant from the N.F.W.O., Belgium. This is manuscript number 640 from the N.I.O.O

\section{LITERATURE CITED}

Allan, J. D., Kinsey, T. G., James, M. C. (1976). Abundances and production of copepods in the Rhode River subestuary of Chesapeake Bay. Chesapeake Sci. 17: 86-92

Bakker, C. , De Pauw, N. (1975). Comparison of plankton assemblages of identical salinity ranges in estuarine tidal, and stagnant environments. II. Zooplankton. Neth. J. Sea Res. 9: 145-165

Bakker, C., Phaff, W. J., Ewijk-Rosier, M. C., De Pauw, N (1977). Copepod biomass in an estuarine and a stagnant brackish environment of the S.W. Netherlands Hydrobiologia 52: 3-13

Bakker, C., Van Rijswijk, P. (1987). Development time and growth rate of the marine calanoid copepod Temora longicomis as related to food conditions in the Oosterschelde estuary (southern North Sea). Neth. J. Sea Res. 21: 125-141

Baretta, J. W. (1980). Het zooplankton van het eems-Dollard estuarium. Soorten, aantallen, biomassa en seizoensfluctuaties. BOEDE - publicaties en verslagen 5: 1-23

Baretta, J. W., Malschaert, J. F. P. (1988). Distribution and abundance of the zooplankton of the Ems estuary (North Sea). Neth. J. Sea Res. 21. 69-81

Belmans, H. (1988). Verdiepings- en onderhoudsbaggerwerken in westeren zeeschelde. Water 43: 184-194

Billen, B., Lancelot, C., De Becker, E., Servais, P. (1988). Modelling microbial processes (phyto- and bacterioplankton) in the Schelde estuary. Hydrobiol. Bull. 22: 43-55

Castel, J., Courties, C. (1982). Composition and differential distribution of zooplankton in Arcachon Bay. J. Plankton Res, 4: 417-433

Castel, J., Veiga, J. (1990). Distribution and retention of the copepod Eurytemora affinis hirundoides (Nordquist. 1888) in a turbid estuary. Mar. Biol. 107 119-128

Collins, N. R., Williams, R. (1981). Zooplankton of the Bristol Channel and Severn Estuary. The distribution of four copepods in relation to salinity. Mar. Biol. 64: 273-283

Collins, N. R., Williams, R. (1982). Zooplankton communities in the Bristol Channel and Severn Estuary. Mar. Ecol. Prog. Ser. 9: 1-11

Day, J. W. Jr, Hall, C. A. S., Kemp, W. M., Yanez-arancibia, A. (eds.) (1989). Estuarine ecology. John Wiley \& Sons, New York, p. 311-337

De Pauw, N. (1973). On the distribution of Eurytemora affinis (Poppe) (Copepoda) in the Western Scheldt estuary. Verh. int. Verein. theor. angew. Limnol 18: 1462-1472

De Pauw, N. (1975). Bijdrage tot de kennis van milieu en plankton in het westerschelde estuarium. Gent thesis, University of Ghent, Ghent

Duursma, E. K., Merks, A. G. A., Nieuwenhuize, J. (1988). Exchange processes in estuaries such as the Westerschelde, an overview. Hydrobial. Bull. 22: 7-20

Fransz, H. G., Colebrook, J. M., Gamble, J. C., Krause, M. (1991). The zooplankton of the North Sea. Neth. J. Sea Res. 28: 1-52

Gauch, H. G. Jr (1982). Multivariate analysis in community ecology. Cambridge University Press, Cambridge

Goosen, N., Van Rijswijk, P., Peene, J., Kromkamp, J. (1992). Annual patterns of bacterial production in the Scheldt estuary (S.W. Netherlands). In: Herman, P. (ed.) JEEP 92: major biological processes in European tidal estuaries. NIOO, Yerseke, p. 115-126

Grice, G. D., Marcus, N. H. (1981). Dormant eggs of marine copepods. Oceanogr. mar. Biol. A. Rev. 19: 125-140

Hansen, J., Fung, I., Lacis, A., Rind, D., Lebedeff, S., Ruedy, R., Russell, G. (1988). Global climate changes as forecast by Goddard Institute for Space Studies three-dimensional model. J. geophys. Res. 93: 9341-9364

Heckman, C. W. (1986). The anadromous migration of a calanoid copepod, Eurytemora affinis (Poppe, 1880) in the Elbe estuary. Crustaceana 50: 176-181

Heip, C. (1988). Biota and abiotic environment in the Westerschelde estuary. Hydrobiol. Bull. 22: 31-34

Heip, C. (1989). The ecology of the estuaries of Rhine, Meuse and Scheldt in the Netherlands. In: Ros, J. D. (ed.) Topics in marine biology. Proc. 22nd European Marine Biology Symposium. Scient. Mar. 53: 457-463

Hill, M. O. (1973). Diversity and evenness: a unifying notation and its consequences. Ecology 54: 427-432

Hill, M. O. (1979). TWINSPAN - a FORTRAN program for arranging multivariate data in an ordered two-way table by classification of the individuals and the attributes Ecology \& Systematics. Cornell University, Ithaca

Hirche, H. J. (1974). Die Copepoden Eurytemora affinis Poppe und Acartia tonsa Dana und ihre Besiedlung durch Myoschiston centropagidarum recht (Peritricha) in der Schlei. Kieler Meeresforsch. 30: 43-64

Hirche, H. J. (1992). Egg production of Eurytemora affinis effect of k-strategy. Est. coast. Shelf Sci. 35; 395-407

Hummel, H., Moerland, G., Bakker, C. (1988). The concomitant existance of a typical coastal and a detritus food chain in the Westerschelde estuary. Hydrobiol. Bull. 22: 35-41

Jongman, R. H. G., Ter Braak, C. J. F., Van Tongeren, O. F. R (1987). Data analysis in community and landscape, ecology. Pudoc, Wageningen

Miller, C. B. (1983). The zooplankton of estuaries. In 
Ketchum, B. H. (ed.) Ecosystems of the world 26: estuaries and enclosed seas. Elsevier, Amsterdam, p. 103-149

Paffenhöfer, G. A., Stearns, D. E. (1988). Why is Acartia tonsa (Copepoda: Calanoida) restricted to nearshore environments? Mar. Ecol. Prog. Ser. 42: 33-38

Peters, J. J., Sterling, A. (1976). Hydrodynamique et transports de sédiments de l'estuaire de l'Escaut. In: Nihoul, J. C. J., Wollast, R. (eds.) Project Mer. Rapport final. Vol. 10. Service de Premier Ministre, Bruxelles, p. 1-65

Roddie, B. D., Leakey, R. J. G., Berry, A. J. (1984). Salinitytemperature tolerance and osmoregulation in Eurytemora affinis (Poppe) (Copepoda: Calanoida) in relation to its distribution in the zooplankton of the upper reaches of the Forth estuary. J. exp. mar. Biol. Ecol. 79: 191-211

Soltanpour-Gargari, A., Wellershaus, S. (1984). Eurytemora affinis - the estuarine plankton copepod in the Weser. Veröff. Inst. Meeresforsch. Bremerhaven 20: 103-117

Stepien, J. C., Malone, C., Chervin, M. B. (1981). Copepod communities in the estuary and coastal plume of the Hudson River. Est. coast. Shelf Sci. 13: 185-195

Tackx, M. L. M., Bakker, C., Francke, J. W., Vink, M. (1989). Size and phytoplankton selection by Oosterschelde zooplankton. Neth. J. Sea Res. 23: 35-43

Ter Braak, C. J. F. (1988). CANOCO - a Fortran program for canonical community ordination by (partial) (detrended) (canonical) correspondence analysis, principal compo-

This article was submitted to the editor nents analysis and redundancy analysis. Version 2.1 . Agricultural Mat. Group, Ministry of Agriculture and Fisheries, Wageningen

Ter Braak, C. J. F. (1989). CANOCO-an extension of DECORANA to analyze species-environment relationships. Hydrobiologia 184: 169-170

Valdes, J. L., Roman, M. R., Alvarez-Ossorio, M. T., Gauzens A. L., Miranda, A. (1990). Zooplankton composition and distribution off the coast of Galicia, Spain. J. Plankton Res. 12: $629-643$

Van Rijswijk, P., Bakker, C., Vink, M. (1989). Daily fecundity of Temora longicornis (Copepoda, Calanoida) in the Oosterschelde estuary (SW Netherlands). Neth. J. Sea Res. 23: 293-303

Van Spaendonk, A., Kronkamp, J, de Visscher, P. (in press). Primary production of phytoplankton in the Westerschelde estuary, The Netherlands. Neth. J. Sea Res.

Vitasalo, M. (1992). Calanoid resting eggs in the Baltic Sea: implications for the population dynamics of Acartia bifilosa (Copepoda). Mar. Biol. 114: 397-405

Villate, F. (1991a). Annual cycle of zooplankton community in the Abra Harbour (Bay of Biscay): abundance, composition and size spectra. J. Plankton Res. 13: 691-706

Villate, F. (1991b). Zooplankton assemblages in the shallow tidal estuary of Mundaka (Bay of Biscay). Cah. Biol. mar. 32: $105-119$

Manuscript first received: October 11, 1991

Revised version accepted: March 10,1993 